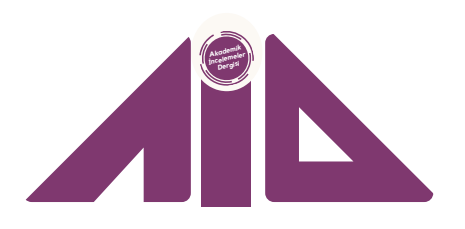

\title{
The European Union and the Treaty on the Prohibition of Nuclear Weapons
}

\author{
Avrupa Birliği ve Nükleer Silahların Yasaklanması Antlaşması
}

\author{
Adviye Damla ÜNLÜ \\ Dr. Arș. Gör., İstanbul Üniversitesi, \\ Sosyal Bilimler Enstitüsü, \\ damla.unlu@istanbul.edu.tr \\ https://orcid.org/0000-0002-5902-4096
}

\section{Araștırma \& Yayın Etiği \\ Bu makale en az iki hakem tarafindan incelenmiş, iThenticate yazılımı ile taranmıș, araștırma yayın ve etiğine aykırıık tespit edilmemiștir.}

\section{BY-NC 4.0}

Bu makale Creative Commons Attribution-NonCommercial License altında lisanslanmıștır.

This paper is licensed under a Creative Commons Attribution-NonCommercial License

\section{Research \& Publication Ethics}

This article was reviewed by at least two referees, a similarity report was obtained using iThenticate, and compliance with research/publication ethics was confirmed.

\section{Copyright $\odot$}

Sakarya Üniversitesi, Sosyal Bilimler Enstitüsü, Sakarya/TÜRKIYE

Sakarya University, Institute of Social Science, Sakarya/TURKEY

\section{Atıf/Citation}

Ünlü, Adviye Damla . "European Union and the Treaty on the Prohibition of Nuclear Weapons". Akademik incelemeler Dergisi 16 / 1 (April 2021): 230-245 .

https://doi.org/10.17550/akademikincelemeler.867503

Makale Türü/Article Type: Araştırma Makalesi/Research Article

Geliş Tarihi/Date Received: 24.01.2021

Kabul Tarihi/Date Accepted: 15.04.2021

Yayın Tarihi/Date Published: 15.04.2021

ISSN: $\quad 1306-7885$

E-ISSN: $2602-3016$

Cilt/Volume: 16 | Sayı/Issue: 1 |

Yll/Year: 2021 (Nisan/April) 


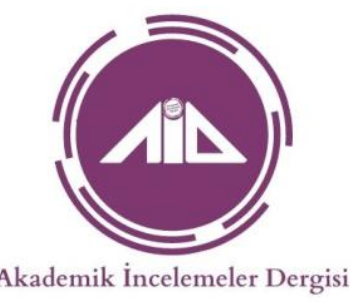

\title{
The European Union and the Treaty on the Prohibition of Nuclear Weapons
}

\begin{abstract}
United Nations General Assembly (UNGA) adopted the Treaty on the Prohibition of Nuclear Weapons (TPNW) on July 7, 2017. The Treaty is a legal instrument that highlights the humanitarian aspect of nuclear disarmament and provides an alternative to the disarmament approach of the NonProliferation Treaty (NPT). Because this Treaty sought to eliminate nuclear weapons, nuclearweapon states (NWS) and states whose security is based on nuclear deterrence, criticized it for weakening the NPT. However, particular states and supranational nongovernmental organizations, such as the International Campaign for the Elimination of Nuclear Weapons (ICAN) opposed nuclear proliferation by carrying out an active, vigorous campaign to ban nuclear weapons and accomplish the goals of the TPNW. Here, two opposing sides emerged on this rather current issue. This study examines the potential of the European Union (EU) which has members from both sides and has policies towards non-proliferation and controlling nuclear weapons since its foundation, to lead and advance the movement of the ban of nuclear weapons, namely the TPNW process. The study intends to determine the strengths and weaknesses of the EU in its support and contribution to the TPNW process, conducting a further discussion on the issue.
\end{abstract}

Anahtar Kelimeler: Non-Proliferation Treaty (NPT), Treaty on the Prohibition of Nuclear Weapons (TPNW), Nuclear Disarmament

\section{Avrupa Birliği ve Nükleer Silahların Yasaklanması Antlaşması}

\section{Öz}

Nükleer Silahların Yasaklanması Antlaşması (TPNW), Birleşmiş Milletler Genel Kurulunda 7 Temmuz 2017 tarihinde kabul edilmiștir. Bu Antlașma ile Nükleer Silahların Yayılmasının Önlenmesi Antlaşmasının (NPT) merkezinde olduğu nükleer silahsızlandırma yaklaşımına alternatif, insani boyutu vurgulanan yeni bir yasal araç geliştirilmiştir. $\mathrm{Bu}$ araç, nükleer silahların tamamen yasaklanmasını öngördügünden özellikle nükleer silah sahibi ve güvenlik anlayışı nükleer caydırıcılığa dayanan ülkeler tarafından eleștirilmiş ve NPT'yi zayıflattığı öne sürülmüştür. Diğer yandan, Nükleer Silahların Kaldırılmasına Yönelik Uluslararası Kampanya (ICAN) başta olmak üzere ulusüstü sivil toplum kuruluşları ile nükleer karşıtı ülkeler, nükleer silahların yasaklanması yönünde aktif ve güçlü bir kampanya yürütmüştür. Bu durumda oldukça güncel olan bu konuda iki taraf oluşmuştur. Bu çalışma, her iki taraftan aktörlerin üyesi olduğu ve kuruluşundan itibaren nükleer silahların kontrolü ve yayılmasının önlenmesi yönünde politikaları olan Avrupa Birliği'nin (AB), nükleer silahların yasaklanması hareketine, diğer bir deyişle TPNW sürecine öncülük etme ve ilerletme potansiyelini analiz etmektedir. Çalışma, AB'nin TPNW sürecine destek ve katkı sağlaması bağlamında güçlü ve zayıf yönlerini belirlemekte ve bu kapsamda bir tartışma yürütmektedir.

Keywords: Nükleer Silahların Yayılmasının Önlenmesi Antlaşması (NPT), Nükleer Silahların Yasaklanması Antlaşması (TPNW), Nükleer Silahsızlanma 


\section{Introduction}

In recent years, external threats, plans for modernization of nuclear weapons, proliferation crisis, the American perspective of transatlantic relations, aggressive policies of Russia, and ineffective NPT review conferences led to more attention is being paid to nuclear non-proliferation by the European governments and the EU. Pressure from civil society and developments such as framing nuclear disarmament as a humanitarian issue also pushes the EU to discuss nuclear disarmament. The "humanitarian turn" on nuclear disarmament took place within the TPNW's signature and its recent entry into force (Davis Gibbons, 2018). This development increased the importance of the distinction between nuclear non-proliferation and disarmament. The fundamental difference between these two concepts is that the former approves the de facto ownership of nuclear weapons by some State-Parties, the latter envisages "irreversible elimination" of weapons by all Parties (Graham, $2020,235)$. The EU has an approach to nuclear non-proliferation and control of nuclear weapons since its establishment. However, the prohibition within the context of disarmament is a relatively current and highly controversial issue on the agenda of the EU and world politics.

Before the intense debates had taken place regarding the ban of nuclear weapons, the EU approach of non-proliferation was to support the multilateral institutions and international norms. The EU has supported nuclear non-proliferation, and consequently, the elimination of nuclear weapons eventually in the NPT's context. Although the goal of eliminating nuclear weapons has been pursued by the EU, the prohibition of nuclear weapons with a new legal instrument has not yet found enough support from the EU and the member states. One of the principal reasons for this is that the member states have different positions regarding the governance of nuclear weapons. Therefore, the EU lacks a common position on the issue. An obstacle to a common position is that France is one of the countries with nuclear weapons. The other one is that the United States (US) has nuclear weapons deployed in four member states, the Netherlands, Germany, Belgium, and Italy.

The first position formed within the framework of these determinants is the Europeanization of France's nuclear weapons and the elimination of US nuclear weapons deployed in the EU. The second one is to support the traditional nuclear deterrence policy of NATO, which is based on a military doctrine that the possibility of using nuclear weapons as retaliation will deter an enemy attack. And lastly, to support gradual disarmament within the framework of Article VI of the NPT or new humanitarian approach and legal instrument, namely the TPNW. In this context, this study aims to analyze the EU's potential to lead and advance the nuclear disarmament movement, the process of TPNW, by specifying the strong and weak sides of the EU on nuclear prohibition beyond the scope of non-proliferation. The study is divided into four sections. The first section gives an overview of the process leading to the signing of TPNW and its actors. Besides, distinguishing features of TPNW from similar treaties and NPT are discussed. Afterward, fundamental criticisms of anti-TPWN countries and NATO are presented. The third section examines the historical development of the nuclear non-proliferation policy of the EU. The fourth and last part of the study discusses the EU approach to nuclear prohibition. Based on this discussion, the study analyzes the EU's strengths and weaknesses in its potential support and contribution to the prohibition of nuclear weapons and a nuclear-free world. 


\section{The Treaty on the Prohibition of Nuclear Weapons}

Global nuclear disarmament is one of the long-standing objectives of the United Nations (UN). In line with this objective, the initial resolution of the UNGA was adopted in January 1946, called for a commission to overcome the problems posed by atomic energy (UNGA, 1946, 9). The resolution aimed to monitor the atomic energy use only for peaceful aims and prevent atomic weapons from becoming part of national armament.

Following the first resolution of the UNGA, the signing of the NPT in 1968 has directed the nuclear weapons issue for a long time. The Treaty became effective on March 5, 1970, from this date, the NPT has been at the center of the disarmament regime on a global scale by providing the normative foundation to the nonproliferation governance and contributing to the prevention of proliferation (Bourantonis, 2015, 44-45). Within the context of the NPT, non-nuclear-weapon states (NNWS) agreed not to attain and develop nuclear weapons. NPT nuclearweapon states (NWS) agreed to assist in the development of nuclear energy with peaceful objectives and work to achieve disarmament (Hincu, 2015, 474-475). It gave the NWS the right to have a nuclear arsenal but also required them to continue negotiations in good faith on effective measures to halt the nuclear arms race and to disarm (NPT, 1968).

Article VI of the NPT that requires gradual disarmament became the key reference point for opponents of nuclear disarmament. However, NWS did not show a tendency to disarmament and did not create a perception in this direction. The modernization of weapons and the expansion of nuclear power have come to the fore. As a result, it has become imperative to create a new normative and legal framework relying on the criticism of anti-nuclear weapon states and civil society by emphasizing potential humanitarian outcomes of the risk of possession and use of nuclear weapons.

Figure 1: Nuclear Forces in the World, January 2019

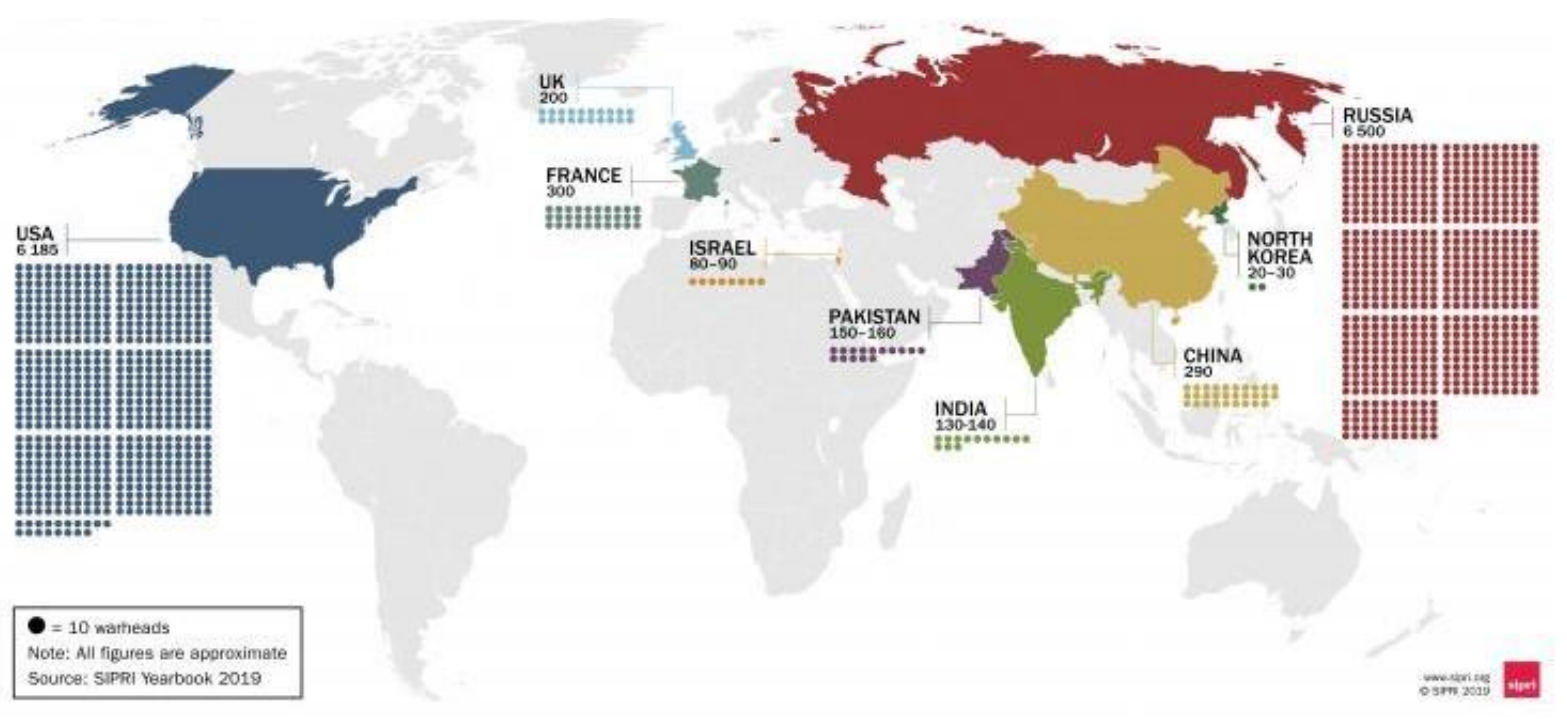

Source: (SIPRI, 2019).

The normative and legal framework for nuclear disarmament was established on July 7, 2017, when a significant part of the UN member states adopted the TPNW. 
The origins of the TPNW in terms of the effectiveness of civil society mobility and the development of the idea of a complete ban on nuclear weapons are based on various previous agreements. The first of these is the prohibition of biological weapons with the "Biological Weapons Convention" that became effective in March 1975. The "Chemical Weapons Convention" banned another weapon of mass destruction (WMD) on April 29, 1997. They were followed by the ban on landmines with the "Anti-Personnel Mine Ban Treaty (Ottawa Convention)" on March 1, 1999, and the prohibition of cluster munitions under the "Cluster Bombs Convention" on August 1, 2010.

Alongside the mobility of civil society and the aforementioned Conventions signed over the years, another factor influencing the process leading to the signing of the TPWN was the ineffectiveness of the NPT review conferences. At the conference held in May 2010, State-Parties at the conference expressed their concern about the humanitarian consequences of any use of nuclear weapons (Final Document, 2010, 19). After the review conference, three humanitarian conferences were organized. Before the first conference, Switzerland delivered the first humanitarian joint statement in the representation of 16 states at the Vienna NPT meeting in 2012. In March 2010, Norway hosted the first humanitarian conference. Mexico held the second one in 2014. Vienna hosted the third conference in 2014. Collectively, these humanitarian meetings and joint statements "became generally described as the humanitarian initiative" (Afina et al., 2017, 2-3). At the last conference, Austria made a pledge that called for all states to specify and set effective legal measures for the prohibition of nuclear weapons (Federal Ministry, December 9, 2014, 2). On December 7, 2015, 138 states in UNGA voted to form an open-ended group to work on legal provisions to achieve nuclear disarmament (UNGA, 2015, 3).

The working group adopted a report recommending a UN conference convened in 2017 open to all states on August 19, 2016. It also called for the attendance of nongovernmental organizations. In the First Committee of the UNGA on October 27, 2016, 123 states voted in favor of a resolution to begin negotiations. Based on this resolution, the conference was convened in March 2017 (UNGA, 2017). It was organized in New York City by two sessions. To preside over sessions, the Ambassador of Costa Rica to the UN in Geneva, Elayne Whyte Gómez was elected President (Afina et al., 2017, 2).

Along with intensified global concern on the potential effect of nuclear weapons, the frustration of many non-nuclear members of the NPT gave impetus to the TPNW. NNWS do not acquire nuclear weapons in keeping with the NPT, while the five NPTrecognized NWS do not tend to progress to the elimination of weapons. Furthermore, the NPT has other shortcomings. Firstly, the normative reach of the NPT does not include the non-signatory states since the NPT regime is treaty-based. Secondly, the status of North Korea under the NPT is not clear. North Korea retreated from the NPT in 2003, but NPT review conferences did not determine its legal status, and still, it is listed as a State-Party on the UN website that shows the status of the Treaty (UN, January 05, 2021).

Thirdly, it is generally accepted that Article VI is legally contentious and arguably weak to oblige NWS to eliminate their weapons (Thakur, 2017, 72-73). In this context, a new instrument as the TPNW could play a significant role in the process of nuclear weapons' loss of legitimacy (Ritchie, 2013,44). The central objective of 
the TPNW is to ban having nuclear weapons by any states that are the party of the Treaty.

TPNW has several distinctive features, and foremost among them is that it frames the possession and use of nuclear weapons as a humanitarian issue before and during the negotiations. In this context, it added a humanitarian dimension to nuclear prohibition, which was not emphasized in the same way before. This new approach emphasized the urgency of owning nuclear weapons and addressing the human consequences of potential use and encouraged states to take steps (Docherty, 2018, 2).

Besides the humanitarian dimension, TPNW has other distinguishing features. Above all, conducting the negotiation and adaptation process of the Treaty by the NNWS made a difference in the status quo of the nuclear disarmament process which was traditionally managed by the NWS. The participation and support of civil society in the process is another prominent feature of TPNW. Also, the attendance of people directly damaged by nuclear weapons has had unprecedented importance in the process (Ruff, 2018, 2). Negotiations of the Treaty took place under the sponsorship of the UNGA and it was adopted by an overwhelming majority that provides the TPNW high credibility. In this context, boycotting states lost their credibility, and their action to prevent the ban of the most destructive weapons brought their sincerity to achieve NPT Article VI into disrepute (Ruff, 2018, 4). Although the NWS opposed and boycotted the negotiations, on July 7, 2017, the TPNW was adopted by 122 votes to 1 , with one abstention. The nine NWS did not attend the conference. NATO members that commit to the nuclear deterrence policy also did not participate. The Netherlands became an exception that voted against the Treaty.

\section{Criticism of the Treaty}

As previously stated, civil organizations and NNWS mainly organized the initiative of nuclear disarmament. However, the NWS opposed the humanitarian initiative, criticizing it for undermining the NPT and destabilizing nuclear politics (Ritchie Egeland, 2018, 1). While states were signing the Treaty, the US, France, and the United Kingdom (UK) declared that they do not approve the Treaty and will not be a party to it. They stated they did not accept the claims regarding the compatibility and contribution of the treaty with customary international law. The three countries have repeated their continued adherence to the NPT and declared their determination to maintain and advance the NPT (Permanent Mission of France to the United Nations, 2017).

Earlier in this joint declaration, the "United States Non-Paper," delivered to the members of NATO on October 17,2016, called on allies that were part of the working group to vote 'no' to the negotiations for a nuclear ban treaty (Hamel-Green, 2018, 441). These initial statements reflect a traditional security approach based on nuclear deterrence. Nevertheless, the joint statement was self-contradictory because the US emphasized its commitment to the NPT, Article VI while stating that it never be a party to the TPNW. On July 9, 2016, NATO also reiterated its position on nuclear prohibition. It emphasized allies' commitment to implementing the NPT and its disarmament objective by adding the "conditions for achieving disarmament are not [currently] favorable" (NATO, 2016). 
Despite the criticism and blocking efforts, the Treaty entered into force with the ratification by the 50 th state, Honduras, on October 24, 2020. It became fully legal for all countries that had ratified or acceded to it by January 22, 2021. After the ratification by the 50th state, a NATO statement was released regarding the Treaty's entry into force on December 15, 2020, and it reiterated NATO's position and its opposition to the TPNW (NATO, 2020).

There has been a powerful opposition to TPNW, notably by NATO and NPTrecognized NWS. Their criticism has been legitimized largely on the grounds of adherence to the NPT and nuclear deterrence. Nonetheless, the entry into force of the Treaty despite serious criticism is a sign that there is also a strong anti-nuclear front against these countries that include both NNWS and civil society.

\section{Non-Proliferation Policy of the European Union}

Regarding non-proliferation, the EU has sui generis features. Firstly, there is one NWS state, and the many member states may have nuclear weapons if they prefer. Secondly, there are diverse opinions on the use of nuclear power between member states. While some member states have commitments to neutrality and disarmament, others do not. Finally, member states have different opinions on transatlantic relations and their relationship with NATO. These features reflect different positions of states on nuclear weapons-related issues and bring the EU to be considered as a microcosm of the multilateral world (Kobia, 2008, 32-33). This consideration, fundamentally based on the divergent standpoints of member states on the non-proliferation and prohibition, highlights the importance of the EU's actorness and position in the nuclear disarmament movement.

Figure 2: Nuclear Forces in the World, January 2019

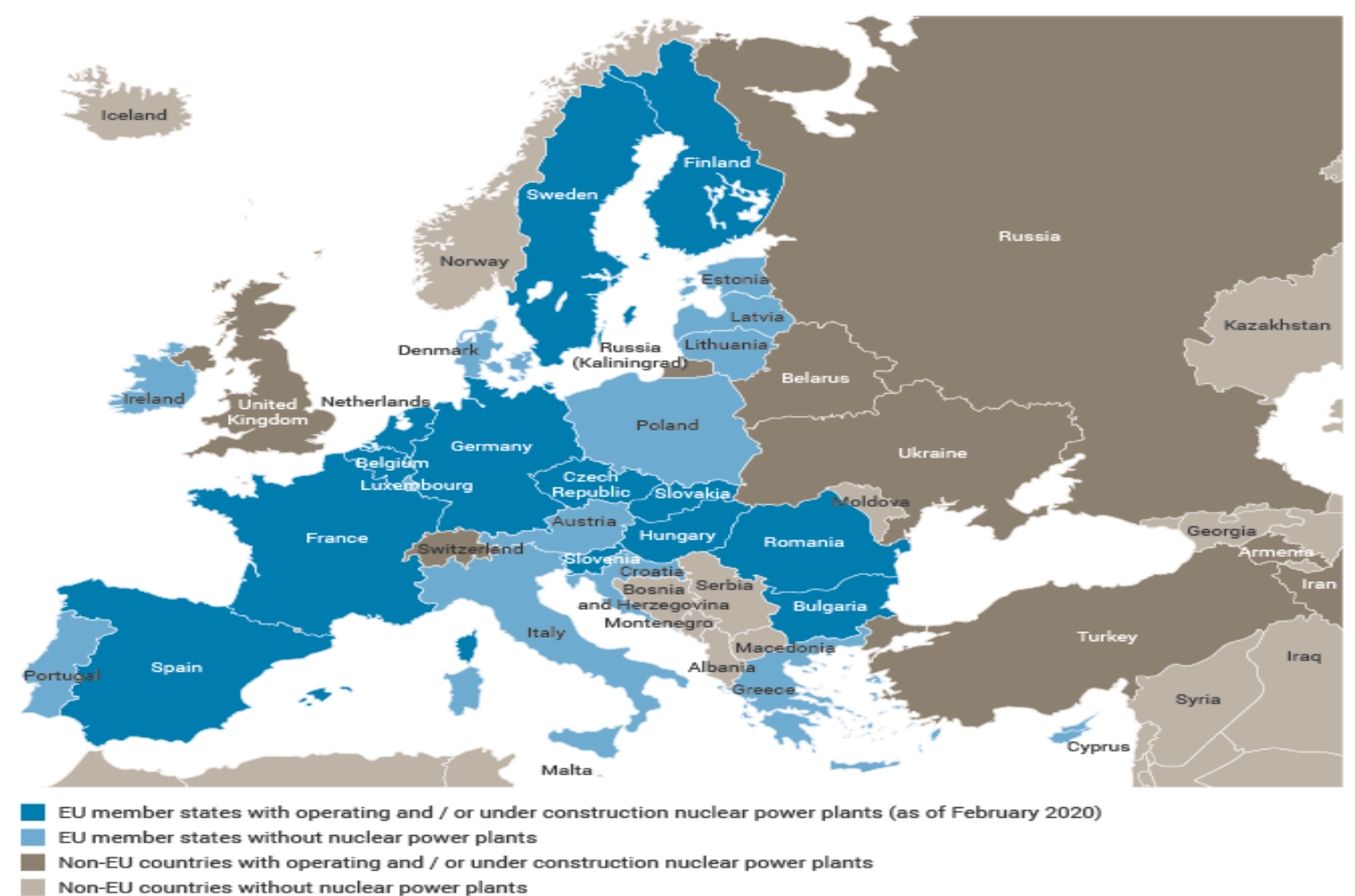

Source: (World Nuclear Association, 2020)

The origin of the EU's non-proliferation policy lies in the European Atomic Energy Community (EURATOM), which was established in 1957 by the Treaty of Rome. 
EURATOM had a clear non-proliferation function and also aimed to foster the development of nuclear energy by controlling the process. The real impetus for the advancement of non-proliferation occurred in the 1980s, especially with the decision to establish a working group in the framework of the European Political Cooperation (EPC). While EURATOM took responsibility to deal with proliferation in the Union, the working group was dealing with promoting non-proliferation in external relations (Portela, 2003, 4). After the Cold War, the strengthening of multilateral approaches towards non-proliferation and disclosure of the Iraqi nuclear program compelled the Union to get more involved in the issue. A third factor that strengthened the EU's role was closer coordination between the member states in terms of foreign policy with the establishment of the CFSP. With the signing of the Treaty on the European Union, "arms control, non-proliferation, and disarmament" became separate initiatives within the scope of the CFSP (Portela, $2003,3)$. Other developments at the beginning of the 1990s were France's accession on the NPT in 1991 and the first statements of the European Council on nonproliferation at the Dublin (1990) and Luxemburg Summits (1991).

The EU took no major steps regarding the non-proliferation between 1994 and 2003 (Kobia, 2008, 35). In the 1990s, the most important step of the EU was its support for the NPT's extension. With the contribution of the EU's initiatives on this issue, in the 1995 review and extension conference, decisions on the indefinite extension and strengthening the review process for the NPT were taken, and the final document was adopted in the 2000 review conference. During the 2000s, the EU slowly took steps to the advancement of its non-proliferation policy. Firstly, the European Council at the Thessaloniki Summit adopted the "EU Strategy against the Proliferation of Weapons of Mass Destruction" in 2003. Strategy confirmed the EU's commitment to a multilateral non-proliferation and disarmament framework (The Council of the European Union, 2003, 6). Thereafter the adaptation of the Strategy, the EU became a significant reference point and has contributed to the nonproliferation regime (Blavoukos et al., 2015, 229). Moreover, as a part of implementing the Strategy, the EU introduced a non-proliferation clause to insert into bilateral agreements to mainstream non-proliferation in its external relations. Besides, the EU intensified its role in the crisis of proliferation as in the cases of Iran and North Korea (Portela, 2015).

The Council Decision adopted on March 29, 2010, explained the position of the EU on non-proliferation as it stated the NPT is emphasized as the "cornerstone of the global nuclear non-proliferation regime" (The Council of the European Union, 2010, 8). In the same year, the "EU Non-Proliferation Consortium" was founded with the Council Decision as a step to implement the 2003 Strategy. The CFSP budget funds the Consortium that includes four core members and 73 independent research institutions. Although external security threats and proliferation crises raised the importance of the non-proliferation policy, funds to non-proliferation declined in the process of time. Besides, the EU Global Strategy 2016 rarely mentioned the word "non-proliferation" and there were "three occasions in the 60-page document, four references to arms control and two mentions of disarmament" (Grip, 2017, 8). These can be considered as a loss of momentum in the promotion of non-proliferation.

\section{The European Union Approach to Prohibition of Nuclear Weapons}

Although the EU has a non-proliferation policy for long years and supports the advancement of the NPT, it does not have a joint position towards the prohibition of 
nuclear weapons. There are various reasons behind this. One of the significant reasons is the divergent views of the EU member states on prohibition. The UK and France traditional supporters of the gradual nuclear disarmament in the scope of NPT, relatedly they support nuclear deterrence policy to achieve national security. Among NATO members, 21 of them are the EU member states, and all of them are part of the nuclear deterrence policy of NATO. And also Germany, the Netherlands, Belgium, and Italy host US tactical nuclear weapons.

EU member states that are members of NATO have boycotted the TPNW negotiations. They did not take part in the conference outside the Netherlands. Austria, Ireland, Cyprus, Malta, and Sweden, EU member states but not NATO members, voted in favor of TPWN at the 2017 UN Conference. Austria, Ireland, and Malta signed and ratified the Treaty. Member states that are not NATO members as Sweden remained under pressure not to sign the Treaty. After the threat of the US Ambassador to NATO and the US Secretary of Defense to Sweden on the ground of partnership with NATO, Swedish Foreign Affairs Minister, Margot Wallström, declared Sweden take its decision after an independent assessment on January 2, 2018 (EPRS, 2018, 4).

On July 12, 2019, she announced the decision not to sign the TPNW. A survey shows\% 78 percent of Swedish people believe Sweden should sign the Treaty (Olof Palme International Center, 2019). Finland is also not a NATO member, however, did not take part in the negotiations and did not vote for the TPNW. Therefore, public opinion in Finland is in favor of the Treaty that a survey shows $84 \%$ of Finns support signing up the TPNW (The Peace Union of Finland, 01 January 2021). In the Netherlands and Germany, as in many NATO members, a significant number of citizens and non-governmental organizations support TPNW. This creates a difficult situation and dilemma for the governments to overcome. Given this situation in the context of NATO, it seems likely that NATO will face a new crisis if the supporters of the TPNW become politically strong enough to ensure the signing of the agreement (Perkovich, 2020).

Figure 3: Vote on The TPNW

\begin{tabular}{|c|c|c|c|}
\hline EU Member State & NATO Member & EU Member State & NATO Member \\
\hline Netherlands & $\checkmark$ & Lithuania & $\checkmark$ \\
\hline Ireland & $x$ & Luxembourg & $\checkmark$ \\
\hline Cyprus & $x$ & Hungary & $\checkmark$ \\
\hline Malta & $x$ & Denmark & $\checkmark$ \\
\hline Austria & $x$ & Belgium & $\checkmark$ \\
\hline Sweden & $x$ & Germany & $\checkmark$ \\
\hline Finland & $x$ & Poland & $\checkmark$ \\
\hline Greece & $\checkmark$ & Portugal & $\checkmark$ \\
\hline Spain & $\checkmark$ & Romania & $\checkmark$ \\
\hline France & $\checkmark$ & Slovenia & $\checkmark$ \\
\hline Croatia & $\checkmark$ & Slovakia & $\checkmark$ \\
\hline Italy & $\checkmark$ & Bulgaria & $\checkmark$ \\
\hline Czechia & $\checkmark$ & Estonia & $\checkmark$ \\
\hline Latvia & $\checkmark$ & United Kingdom & $\checkmark$ \\
\hline
\end{tabular}

Absent-For-Against

Source: (EPRS, 2018) 
Ian Manners defined the EU as a normative power by arguing the EU promoting the principles of the UN system (Manners, 2002; 2008, 46). Since then, the ability of the EU to the promotion of values and norms to third countries and world politics is a matter of discussion. Nuclear disarmament is considered as another field "in which the EU has deployed its normative power" (Hincu, 2015, 475). Therefore, the EU's role as a global actor is promising on the issue of nuclear disarmament and diffusion of the new humanitarian disarmament norm.

Although the first effect after the entry into force of the Treaty was limited, approval by 100 states constituted the psychological threshold according to Thakur (Thakur, $2017,86)$. Ratification by the key states, especially by NATO members, accompanied by pressure from European civil society, could strengthen the TPNW and also the global nuclear disarmament movement. The humanitarian initiative that includes some EU member states focuses on the humanitarian outcomes of the continuation of global politics that is based on the possession of nuclear weapons. This initiative stigmatizes nuclear weapons and NWS, which may contribute to the elimination of nuclear weapons. TPNW may persuade NWS and its supporters to comply with norms against nuclear armament (Sauer - Reveraert, 2018, 19).

Traditionally NPT review conferences provide a significant ground for the advancement of nuclear disarmament in the norm diffusion process. Before the conferences, the EU generally reiterates its commitment to multilateralism and international forums and tries to achieve a common position. Therefore, the EU stated its commitment to ensuring the achievement of the 2020 review conference. The EU PrepCom pointed out the significance of nuclear disarmament by emphasizing the need to expand the nuclear arms reduction treaty (New START) between the US and Russia, an active dialogue between Russia and the US on the Intermediate-Range Nuclear Forces Treaty, ratification of the Comprehensive Nuclear-Test-Ban Treaty, urgent deliberations on a Fissile Material Cut-off Treaty (European Union, 2018, 4-8).

There were also other PrepComs of distinct groups and states as Nordic countries, Austria, and ICAN that supported the TPWN directly. The Nordic countries $(2018,2-$ 3) stated that they have different perspectives on the TPNW negotiations, however, they agree on the humanitarian outcomes of the use of weapons putting humanity at constant risk. Although they have different positions on TPNW, they are united on the humanitarian dimension of the Treaty. Austria PrepCom also highlighted that nuclear weapons pose a risk to humanity and evaluated the TPNW as a contribution to the fulfillment of Article VI of the NPT (General Debate Statement Austria, 2018, 2). This discourse was developed against criticism of anti-TPNW countries that the TPNW undermined the NPT regime. The Austrian committee stated that the NPT is fully compatible with the TPNW. ICAN's PrepCom $(2018,2)$, which has one of the biggest contributions in the process of signing the TPNW, applauded the states that signed and ratified the agreement and urged everyone else to follow their lead. These statements show a powerful will for the prohibition process. In this context, Nordic countries, Austria, other non-NATO members among the EU member states, civil society organizations may advance the issue of disarmament in the EU and contribute to achieving a concerted action. Besides, the EU has the potential to lead the international community towards nuclear disarmament.

The EU to be an effective actor on the issue should show institutional will alongside supports of member states. In this process, the European Parliament came into 
prominence among the EU institutions by recommending to take further steps for nuclear disarmament. In this respect, the European Parliament recommended opening negotiations on the formation of a legally-binding tool for the elimination of nuclear weapons in 2017 (EPRS, 2018, 4). Another recommendation was issued in 2020, and it urged the Union "to adopt a common EU position as regards the NPT Review Conference" (European Parliament, 2020, 5). It pointed out that the conference takes place in a challenging international environment where nuclear weapons and delivery vehicles are being modernized or planned to be modernized. In return, High Representative of the Union Josep Borrell assured the members of the European Parliament that the EU works to prevent the increase of polarization between the member states and to establish a common ground between them (Borrell, 2020).

After the conclusion of the Brexit process, France has become the only NWS in the EU. And the fact remains that 21 EU member states are also NATO members. That makes nuclear disarmament essentially a European issue along with the possibility of Europe's destruction in the event of a conflict and Europe's preference to effect change through rules-based processes (Tuomioja, 2020). This is a very significant reason to discuss and keep the future direction of the EU in terms of nuclear weapons on the agenda. Because of the divergent opinions of member states, the nuclear weapons policy of the EU is discussed aloud to prohibit deepening of dissent.

There are different scenarios for the future of nuclear weapons in the EU. Among them, Europeanization of the French nuclear weapons, delegitimization and elimination and maintenance of the status quo come into prominence (Sauer, 2020, 12). Regarding the first scenario, the President of France stated the nuclear forces of France have a deterrent effect, especially in Europe, and "they strengthen the security of Europe through their very existence" (Macron, 2020). With this speech, Macron reiterated France's commitment to nuclear deterrence. However, it has a European dimension, autonomous from transatlantic relations. It is possible for France to Europeanized its nuclear weapons, in case of supports from other states, notably Germany. However, instead of taking a step further to disarmament, replacing the US nuclear deterrent role with France would strengthen the NNWS's growing perception that disarmament is not the ultimate goal of the NWS in the context of Article VI of the NPT, and deepen insecurity (Jasper and Portela, 2010, 163). This perception and insecurity find its response in societies as well. The growing anti-nuclear tendency in Europe is another powerful obstacle for the development of a European deterrent. Polls show that majority of public opinion is in favor of the idea of nuclear disarmament and supports their countries to sign the TPNW. Support for TPNW is at the level of $60-70 \%$ in Sweden, Finland, Italy, Germany, France, and Belgium (Fihn-Högsta, 25 November 2020).

Public opinion and the dynamism of civil society raise the importance of the subject in domestic politics. For instance, there is a positive reference to TPNW in the declaration published after the establishment of the coalition government in Belgium (ICAN, 05 January 2021). This is important as it is the first positive reference made by a NATO member country to TPNW, and it shows that the issue was approached in the formation of the coalition government. Also, 56 politicians from 20 NATO members, Japan and South Korea, including two former NATO Secretary Generals, Javier Solona and Willy Claes, and former head of states, prime ministers, and foreign and defense ministers, called on their governments to sign 
the Treaty (Gladstone, 2020). In the signature campaign organized by ICAN, the number of parliamentarians who made the same call reached over 1600 (ICAN, 04 January 2021). All these developments indicate increasing support for TPNW in the European public and political circles. The growing support for the TPNW makes it is unlikely for governments and the EU to ignore the nuclear disarmament movement.

\section{Conclusion}

The prohibition of nuclear weapons is a current issue that gets strength from civil society, public opinion, and NNWS. Against the global anti-nuclear movement, which has existed for a long time and whose primary aim is nuclear prohibition, there are NWS and a traditional understanding of security based on nuclear deterrence. In this respect, although the inurement of the TPNW is a significant achievement for the anti-nuclear movement, it is early to say whether it promises a nuclear-free world.

In the TPNW process, the EU member states are among the most influential states, Austria being the leading. They are expected to shape the norm against nuclear armament and to strengthen the nuclear disarmament agenda based upon Article XII of the TPNW that call State-Parties to encourage non-State-Parties to join the Treaty.

Figure 4: Strengths and Weaknesses of the EU to Advancement of the TPNW Process

\begin{tabular}{|l|l|}
\hline Strengths & Weaknesses \\
\hline Member States Supporting TPNW & Lack of a Common Position \\
\hline Enduring Commitment to Multilateralism & Commitment to the Nuclear Deterrence \\
\hline $\begin{array}{l}\text { Change in Discourse from Proliferation to } \\
\text { Prohibition }\end{array}$ & Prohibition not being a Priority Issue \\
\hline Public Support for the Prohibition & \\
\hline
\end{tabular}

There are instances of the advancement of some policy areas by the leading of particular EU member states. Sweden is leading by example for the adoption of feminist foreign policy. Germany and Denmark are leading states for prioritizing green transition. Austria and other TPNW supporting states have the potential to achieve the normative and then political transformation on nuclear disarmament, despite their quantitative weakness.

The commitment of the EU to multilateralism is another strength in advancing the TPNW process. This commitment is constantly emphasized on non-proliferation, as it is expressed and practiced in various subjects such as trade and the environment. Besides, discourse on non-proliferation has developed to discourse on nuclear prohibition within time. The European Parliament comes to the fore in this discursive transformation. The activism and support of European citizens and civil society accompanied Parliament's institutional efforts to prohibition. Considering the determining role of public opinion and civil society in the policymaking process in the EU, it can be evaluated as a significant pressure tool. Divergent opinions of the member states on nuclear prohibition and the lack of a common position in foreign relations are among the obstacles for the EU to support and contribute to the TPNW process. Besides, EU member states against the TPNW create a dichotomy between the NPT and the TPNW as other anti-TPNW states. The EU member states 
supporting the NPT against the TPNW are NATO members, and they express their commitments to NATO's understanding of security, which is based on nuclear deterrence. Finally, nuclear disarmament is not one of the priorities of the EU. Despite the potential destructive outcomes of the use of nuclear weapons for the European continent and the world, it is not among the priority issues on the agenda of global politics for the moment. 


\section{References}

Afina, Yasmin et al. Negotiating of a Nuclear Weapons Prohibition Treaty: Nuts and Bolts of the Ban, The New Treaty: Taking Stock. UNIDIR, 2017.

Blavoukos, Spyros et al. "Assessing the EU's Performance in the Field of Nuclear Non-Proliferation". EU and the Non-Proliferation of Nuclear Weapons. ed. Spyros Blavoukos et al. 227-241. London: Palgrave Macmillan, 2015.

Borrell, Josep. "Non-Proliferation Treaty: Remarks by the High Representative/VicePresident Josep Borrell at the EP on the Preparation of the 2020 NPT Review Process, Arms Control and Nuclear Disarmament Options". Accessed 01 January 2021. https://eeas.europa.eu/headquarters/headquartershomepage/87277/non-proliferation-treaty-remarks-highrepresentativevice-president-josep-borrell-ep en

Bourantonis, Dimitris "The International Nuclear Non-Proliferation Policy Framework under the NPT and Related Instruments". EU and the NonProliferation of Nuclear Weapons. ed. Spyros Blavoukos et al. 33-47. London: Palgrave Macmillan, 2015.

Davis Gibbons, Rebecca. "The Humanitarian Turn in Nuclear Disarmament and the Treaty on the Prohibition of Nuclear Weapons". The Nonproliferation Review (2018), 1-26.

Docherty, Bonnie. “A 'light for all humanity': The Treaty on the Prohibition of Nuclear Weapons and the Progress of Humanitarian Disarmament". Global Change, Peace \& Security 30/2 (2018), 1-24.

EPRS, European Parliament Research Service. Treaty on the Prohibition of Nuclear Weapons-the Ban Treaty.

(2018). https://www.europarl.europa.eu/thinktank/en/document.html?reference= EPRS BRI(2018)614664

European Parliament. "Recommendation of 21 October 2020 (2020/2004(INI))". Accessed $03 \quad$ January 2021. https://www.europarl.europa.eu/doceo/document/TA-9-20200281 EN.pdf

European Union. "Preparatory Committee for the 2020 Review Conference of the Parties to the Treaty on the Non-Proliferation of Nuclear Weapons (NPT), 2018". Accessed 03 January 2021. https://reachingcriticalwill.org/images/documents/Disarmamentfora/npt/prepcom18/statements/23April EU.pdf

Federal Ministry, Republic of Austria. "Austrian Pledge, 9 December 2014". Accessed 01 January 2021.

https://www.reachingcriticalwill.org/images/documents/Disarmamentfora/vienna-2014/Austrian Pledge.pdf

Final Document. "Review Conference of the Parties to the Treaty on the Non-Proliferation of Nuclear Weapons, 2010". Accessed 02 January 2021. https://undocs.org/NPT/CONF.2010/50\%20(VOL.I)

General Debate Statement Austria. "Austria Preparatory Committee for the 2020 Nuclear Non-Proliferation Treaty Review Conference, 2018”. Accessed 01 January 2021. https://reachingcriticalwill.org/images/documents/Disarmamentfora/npt/prepcom18/statements/23April Austria.pdf

Gladstone, Rick, Former World Leaders Urge Ratification of Nuclear Arms Ban Treaty, The New York Times, 20 September 2020. 
https://www.nytimes.com/2020/09/20/world/treaty-nuclear-armsunited-nations.html

Graham, Kennedy. "The TPNW Conference of Parties: What Is to Be Discussed?", Journal for Peace and Nuclear Disarmament 3/2 (2020), 234-252.

Grip, Lina. The European Union and Non-Proliferation, 2014-17. EU Non-Proliferation Consortium Final Report, 2017.

Hamel-Green, Michael. "The Nuclear Ban Treaty and 2018 Disarmament Forums: An Initial Impact Assessment". Journal for Peace and Nuclear Disarmament 1/2 (2018), 436-463.

Hincu, Roxana. EU's Policy of Disarmament as Part of its Normative Power. CES Working Papers 7/2a, 2015.

ICAN, International Campaign to Abolish Nuclear Weapons. "Statement of the ICAN to the Non-Proliferation Treaty Preparatory Committee, 2018". Accessed 03 January

2021.

https://reachingcriticalwill.org/images/documents/Disarmamentfora/npt/prepcom18/statements/25April ICAN.pdf

ICAN. "People and Structure". Accessed 03 January 2021. https://www.icanw.org/people and structure

ICAN. "Full List of Pledge Takers". Accessed 04 January 2021. https://pledge.icanw.org/full list of pledge takers

ICAN. "Belgian Government Shifts Stance on TPNW". 05 January 2021. https://www.icanw.org/belgium tpnw shift

Jasper, Ursula - Portela, Clara. "EU Defense Integration and Nuclear Weapons: A Common Deterrent for Europe?". Security Dialogue 41/2 (2010), 145-168.

Kobia, Roland. "The EU and Non-Proliferation: Need for a Quantum Leap?". Nuclear Law Bulletin 1 (2008), 31-53.

Macron, Emmanuel. "Speech of the President of the Republic on the Defense and Deterrence Strategy". Accessed 02 January 2021. https://www.elysee.fr/en/emmanuel-macron/2020/02/07/speech-of-thepresident-of-the-republic-on-the-defense-and-deterrence-strategy

Manners, Ian. "Normative Power Europe: A Contradiction in Terms?". JCMS: Journal of Common Market Studies 40 (2002), 235-258.

Manners, Ian. "The Normative Ethics of the European Union". International Affairs, 84, (2008), 45-60.

NATO, North Atlantic Treaty Organization. "Warsaw Summit Communiqué, 2016". Accessed 03 January

2021.

https://www.nato.int/cps/en/natohq/official texts 133169.htm

NATO. "North Atlantic Council Statement as the Treaty on the Prohibition of Nuclear Weapons Enters into Force, 2020". Accessed 05 January 2021. https://www.nato.int/cps/en/natohq/news 180087.htm

Nordic Countries. "General statement by the Nordic countries Preparatory Committee for the 2020 NPT Review Conference, 2018". $\begin{array}{llll}\text { Accessed } & 03 & \text { January }\end{array}$

https://reachingcriticalwill.org/images/documents/Disarmamentfora/npt/prepcom18/statements/23April NordicGroup.pdf

NPT, Treaty on the Non-Proliferation of Nuclear Weapons, United Nations Office for Disarmament Affairs, 1968. Accessed 01 January 2021. https://www.un.org/disarmament/wmd/nuclear/npt/text 
Olof Palme International Center. "The Swedish People are in Favor of a Nuclear Ban, 2019". Accessed 03 January 2021. https://www.palmecenter.se/svenskafolket-ar-for-ett-karnvapenforbud/

Perkovich, George. "Living with the Nuclear Prohibition Treaty: First, Do No Harm". Carnegie Endowment for International Peace (10 November 2020). https://carnegieendowment.org/2020/11/10/living-with-nuclearprohibition-treaty-first-do-no-harm-pub-83198

Permanent Mission of France to the United Nations, July 7, 2017". Accessed 01 January 2021. https://onu.delegfrance.org/Adoption-of-a-treaty-banningnuclear-weapons

Portela, Clara. The Role of the EU in the Non-Proliferation of Nuclear Weapons: The Way to Thessaloniki and Beyond. PRIF Reports 65, 2013.

Portela, Clara. "EU Strategies to Tackle the Iranian and North Korean Nuclear Issues". EU and the Non-Proliferation of Nuclear Weapons. ed. Spyros Blavoukos et al. 188-204. London: Palgrave Macmillan, 2015.

Ritchie, Nick. "Legitimizing and Delegitimizing Nuclear Weapons". Viewing Nuclear Weapons through a Humanitarian Lens. ed. John Borrie-Tim Coughley. 44-75. Geneva: United Nations Institute for Disarmament Research, 2013.

Ritchie, Nick-Egeland, Kjølv. "The Diplomacy of Resistance: Power, Hegemony and Nuclear Disarmament". Global Change, Peace \& Security 30/2 (2018), 1-19.

Ruff, Tilman. "Negotiating the UN Treaty on the Prohibition of Nuclear Weapons and the Role of ICAN". Global Change, Peace \& Security 30/2 (2018), 1-20.

Sauer, Tom. "Power and Nuclear Weapons: The Case of the European Union". Journal for Peace and Nuclear Disarmament 3/1 (2020), 1-19.

Sauer, Tom-Reveraert, Mathias. "The Potential Stigmatizing Effect of the Treaty on the Prohibition of Nuclear Weapons". The Nonproliferation Review 25/5, 119.

SIPRI, Stockholm International Peace Research Institute, 2019. Accessed 03 January 2021. $\quad$ https://www.sipri.org/research/armament-anddisarmament/nuclear-disarmament-arms-control-and-nonproliferation/world-nuclear-forces

Thakur, Ramesh. "The Nuclear Ban Treaty: Recasting a Normative Framework for Disarmament". The Washington Quarterly 40/4 2017, 71-95.

The Council of the European Union, 2003/15708/3. Accessed 03 January 2021. https://data.consilium.europa.eu/doc/document/ST-15708-2003INIT/en/pdf

The Council of the European Union, 2010/212/CFSP. Accessed 03 January 2021. https://eur-lex.europa.eu/legalcontent/EN/TXT/?uri=CELEX\%3A32010D0212

The Peace Union of Finland. "84\% of Finns Want the Government to Join the TPNW". Accessed 01 January 2021. https://rauhanliitto.fi/en/rauhanliittoen/articles/press-releases/84-of-finns-want-the-government-to-join-thetpnw

TPNW, Treaty on the Prohibition of Nuclear Weapons, United Nations Office for Disarmament Affairs, 2017. Accessed 01 January 2021. http://disarmament.un.org/treaties/t/tpnw/text 
Tuomioja, Erkki. "It is Time to End our Reliance on Nuclear Weapons". European Council on Foreign Relations (2 November 2020). https://ecfr.eu/article/itis-time-to-end-our-reliance-on-nuclear-weapons/

UN, United Nations. "Tenth Review Conference of Parties to the Treaty on the NonProliferation of Nuclear Weapons". Accessed 04 January 2021. https://www.un.org/sites/un2.un.org/files/npt presidentdesignate letter 28 oct 2020.pdf

UN. "Treaty on the Non-Proliferation of Nuclear Weapons-Status of the Treaty". Accessed 05 January 2021. http://disarmament.un.org/treaties/t/npt

UNGA, United Nations General Assembly. "Resolutions Adopted on the Reports of the First Committee, 1946". Accessed 03 January 2021. https://undocs.org/en/A/RES/1(I).

UNGA. "Taking forward Multilateral Nuclear Disarmament Negotiations, 2015". Accessed 03 January

2021. https://www.un.org/ga/search/view doc.asp?symbol=A/C.1/70/L.13/Rev. $\underline{1}$

UNGA. "Report of the United Nations Conference to Negotiate a Legally Binding Instrument to Prohibit Nuclear Weapons, Leading Towards their Total Elimination, 2017". Accessed 03 January 2021. https://undocs.org/A/72/206

United Nations Treaty Collection, 1975". Accessed 03 January 2021. https://front.un-arm.org/wp-content/uploads/2020/12/BWC-textEnglish.pdf

United Nations Treaty Collection, 1997". Accessed 03 January 2021. https://treaties.un.org/doc/Treaties/1997/04/19970429\%200752\%20PM/CTC-XXVI_03_ocred.pdf

United Nations Treaty Collection, 1999". Accessed 03 January 2021. https://treaties.un.org/doc/Treaties/1997/09/19970918\%200753\%20AM/Ch_XXVI_05p.pdf

United Nations Treaty Collection, 2010. Accessed 03 January 2021. https://treaties.un.org/Pages/ViewDetails.aspx?src=TREATY\&mtdsg_no=X XVI-6\&chapter $=26 \&$ clang=_en

World Nuclear Association, 2020. Accessed 01 January 2021. https://www.worldnuclear.org/information-library/country-profiles/others/europeanunion.aspx\#: :text=EU\%20nuclear\%20generation $\% 20$ capacity,in $\% 20$ only \%20one $\% 20$ country $\% 20 \% \mathrm{E} 2 \% 80 \% 93 \% 20$ France 